\title{
Blood Vessel Maturation in Human Uveal Melanoma: Spatial Distribution of Neovessels and Mature Vasculature
}

\author{
Yolanda Piña Colleen M. Cebulla Timothy G. Murray Armando Alegret \\ Sander R. Dubovy Hinda Boutrid William Feuer Lejla Mutapcic \\ Maria-Elena Jockovich \\ Department of Ophthalmology, Bascom Palmer Eye Institute, University of Miami Miller School of Medicine, \\ Miami, Fla., USA
}

\section{Key Words}

Uveal melanoma · Angiogenesis • Vessel maturation

\begin{abstract}
Purpose: The aims of this study are (1) to evaluate the spatial distribution of neovessels and mature vessels in human uveal melanoma tumors and (2) to determine whether vessel maturation is associated with the major indicators for poor prognosis. Methods: Immunohistochemical analyses were performed on human tissue specimens from enucleated eyes ( $n=14$ ) to assess total vessels, neovessels, mature vessels, and cell proliferation. Tumor morphology was analyzed by hematoxylin and eosin and modified periodic acid-Schiff (PAS) staining. The spatial distribution of neovessels and mature vessels was analyzed by immunohistochemistry, and correlated with major indicators of poor prognosis (i.e., aggressive PAS patterns, epithelioid cytology, mitotic figures, extraocular extension, anterior tumor location, ciliary body involvement, large tumor size, cell proliferation, and angiogenic activity). Results: Neovessel density was greater than mature vessel density in apical $(p=0.17)$, central $(p=0.036)$,
\end{abstract}

and peripheral ( $p=0.31$ ) regions of the tumors, while mature vessel density was greater than neovessel density in basal areas of the tumor $(p=0.47)$. This pattern indicated that vessel maturation begins at the base of the tumor and later extends to the peripheral and apical regions. The difference between mature and neovessel densities for the apical $(-0.8 \pm 1.9)$ and central areas $(-0.8 \pm 1.3)$ of the tumor was significantly higher than the difference obtained for the basal area $(0.3 \pm 1.6 ; p=0.014$ and $p=0.012$, respectively), indicating a higher density of mature vessels compared to neovessels at the base. Statistical correlations were found between mature vessel density and tumor size $(r=0.48, p=$ $0.084)$, cell proliferation $(r=0.62, p=0.042)$, and mitotic figures $(r=0.76, p=0.001)$. Conclusions: Significant differences exist in the spatial distribution of mature versus neovessels in human uveal melanoma. Vessel maturation is associated with known clinical and pathologic indicators of poor prognosis (e.g., cell proliferation). Antiangiogenic therapy should be considered for the treatment of ocular malignancies; however, the results of this study indicate that blood vessel maturation heterogeneity may limit the efficacy of vessel targeting agents.

Copyright $\odot 2009$ S. Karger AG, Basel

\section{KARGER}

๑๐ 2009 S. Karger AG, Basel

Fax +41613061234 E-Mail karger@karger.ch www.karger.com www.karger.com/ore
Timothy G. Murray, MD

Bascom Palmer Eye Institute

PO Box 016880

Miami, FL 33101 (USA)

Tel. +1 305326 6166, Fax +1 305326 6147, E-Mail tmurray@med.miami.edu 


\section{Introduction}

Uveal melanoma occurs in approximately 1,200 patients per year in the United States. Although rare, this is the most common primary intraocular malignancy in adults $[1,2]$, with large tumors carrying a mortality rate of almost 50\% due to metastasis [3-5]. Efforts have been made to develop therapeutic tools to treat the tumor more effectively. Currently, $30-50 \%$ of cases with uveal melanoma undergo enucleation due to uncontrolled tumor proliferation.

A number of factors have been associated with poor prognosis and death due to metastasis in uveal melanoma. These include aggressive periodic acid-Schiff (PAS) patterns [6], epithelioid cytology [4], mitotic figures [7, 8], tumor size $[9,10]$, extraocular extension $[4,11]$, anterior tumor location [12-14], ciliary body involvement [4, 15], macrophage density [16], high microvascular density [17], cell proliferation [18], angiogenic activity [18, 19], and chromosomal abnormalities (e.g., monosomy 3) [20]. Among these factors angiogenic activity is of interest since novel therapeutic agents currently under study include vessel targeting agents.

Angiogenesis, the formation of new blood vessels from preexisting ones, has been widely recognized to be a biological indicator of tumor formation and proliferation $[18,21-23]$. Since angiogenesis plays an essential role in tumor proliferation and metastasis, attention has been focused on antiangiogenic treatments in a number of ocular tumors [24-28]. However, reports from studies in a mouse model of pancreatic islet cancer suggest that antiangiogenic therapy mainly prevents tumor growth with less effect on tumor regression [29]. In a mouse model of retinoblastoma, we have shown that the antiangiogenic steroid derivative anecortave acetate effectively reduces tumor burden in small tumors with high angiogenic activity [30]. However, this effect was diminished in larger tumors with significant tumor blood vessel maturation [31]. In other models, adding pericyte inhibitors to target mature vasculature in addition to antiangiogenic agents enhances tumor regression [29]. In an orthotopic model of uveal melanoma, selective targeting of pericytes reduces tumor vessel density and tumor burden [32].

The vascular system of uveal melanomas is highly complex including blood vessels and tumor-lined channels. Vessel density has been detected in these tumors using markers against CD34 [17] and factor VIII-related antigen [33]. Folberg et al. [34] and Maniotis et al. [35] demonstrated that aggressive melanoma cells create tumor-lined channels which are similar to blood vessels, but lack endothelial cells (ECs). The formation of these tumor cell-lined, PAS-positive channels is called 'vasculogenic mimicry'. Recently, angiogenic activity was assessed by the detection of neovessels using CD105 immunoreactivity $[18,19]$. Angiogenic activity in these tumors has been significantly associated with death due to metastasis $[18,19]$. Mature vessels have been also detected in these tumors by staining with $\alpha$-smooth muscle actin ( $\alpha$-SMA) [17]. The presence and spatial distribution of neovessels as well as mature vessels in human uveal melanoma tumors may impact the efficacy of antiangiogenic therapies, and may dictate the therapeutic strategies used. To the best of our knowledge, the spatial distribution of vessel maturation in uveal melanoma has not been assessed.

The aims of this study are to (1) evaluate the spatial distribution of neovessels versus mature vessels in this malignancy and (2) determine if vessel maturation is associated with the major indicators for poor prognosis in uveal melanoma.

\section{Methods}

Human Tissue Specimens

This study was conducted in adherence with the tenets of the Declaration of Helsinki and the University of Miami Institutional Research Board. Human uveal melanoma tissue samples were consecutively obtained between the dates September 21, 2005 and August 27, 2006, from 14 patients ( 7 females and 7 males; median age: 56.5 years; age range: $13-86$ years) who underwent enucleation due to extensive tumor at presentation at the Bascom Palmer Eye Institute (table 1).

The following factors were considered indicators of poor prognosis and were correlated with the presence and distribution of mature tumor vessels: highly aggressive PAS patterns (networks and loops) [6], epithelioid cytology [4], mitotic figures [7, 8], extraocular extension $[4,11]$, anterior tumor location [12-14], ciliary body involvement $[4,15]$, large tumor size $[9,10]$, cell proliferation [18], and angiogenic activity [18, 19].

Hematoxylin and Eosin and Modified PAS

Enucleated eye specimens were fixed with $10 \%$ formalin, embedded in paraffin, and sectioned $(8 \mu \mathrm{m})$. Slides were stained with hematoxylin and eosin (H\&E) and modified PAS. The H\&E stain was performed in previously bleached tissues and the PAS stain was modified by omitting the Harris hematoxylin or light green counterstain [34].

Each tumor area (i.e., base, center, apex, peripheral edges) was examined using a green filter for the distribution of the following PAS patterns: silent, straight, parallel, parallel with cross-links, arcs, arcs with branching, loops, and networks. These patterns have been previously described [6]. Although there is some debate regarding which PAS patterns are associated with worse prognosis, loops and networks have been shown by various groups to 
Table 1. Summary of tumor characteristics

\begin{tabular}{|c|c|c|c|c|c|c|c|c|c|c|}
\hline \multirow{2}{*}{$\begin{array}{l}\text { Tumor } \\
\text { No. }\end{array}$} & \multirow{2}{*}{$\begin{array}{l}\text { Tumor } \\
\text { area } \\
\mathrm{mm}^{2}\end{array}$} & \multirow{2}{*}{$\begin{array}{l}\text { Anatomic } \\
\text { location }\end{array}$} & \multirow{2}{*}{$\begin{array}{l}\text { Histologic } \\
\text { type }^{\mathrm{a}}\end{array}$} & \multirow{2}{*}{$\begin{array}{l}\text { Mitotic } \\
\text { figures per } \\
40 \mathrm{HPF}\end{array}$} & \multirow{2}{*}{$\begin{array}{l}\text { Extraocular } \\
\text { extension, \% } \\
\text { scleral involvement }\end{array}$} & \multirow[t]{2}{*}{ Location } & \multicolumn{3}{|c|}{ Average grading densities } & \multirow{2}{*}{$\begin{array}{l}\text { Aggressive } \\
\text { vascular patterns } \\
\text { loops/networks }\end{array}$} \\
\hline & & & & & & & $\alpha$-SMA & CD105 & Ki-67 & \\
\hline \multirow[t]{4}{*}{1} & 45.9 & $\mathrm{C}, \mathrm{CB}$ & mixed & 11 & & base & 5.0 & 4.3 & 3.8 & \\
\hline & & & & & & center & 3.7 & 3.7 & 3.8 & \\
\hline & & & & & & apex & 5.0 & 3.7 & 4.1 & \\
\hline & & & & & & periphery & 5.0 & 4.7 & 3.9 & \\
\hline \multirow[t]{4}{*}{2} & 28.8 & $\mathrm{C}$ & spindle & 0 & $50^{b}$ & base & 1.0 & 1.7 & 2.7 & \\
\hline & & & & & & center & 1.0 & 1.7 & 2.9 & + \\
\hline & & & & & & apex & 2.0 & 1.7 & 2.2 & \\
\hline & & & & & & periphery & 1.8 & 1.3 & 2.5 & \\
\hline \multirow[t]{4}{*}{3} & 132.9 & $\mathrm{C}, \mathrm{CB}$ & mixed & 4 & 15 & base & 3.0 & 3.0 & 3.5 & + \\
\hline & & & & & & center & 3.0 & 2.3 & 3.4 & \\
\hline & & & & & & apex & 3.0 & 3.3 & 3.0 & \\
\hline & & & & & & periphery & 3.5 & 2.2 & 3.1 & + \\
\hline \multirow[t]{4}{*}{4} & 32.4 & $\mathrm{C}, \mathrm{CB}$ & mixed & 2 & 10 & base & 2.3 & 2.0 & & \\
\hline & & & & & & center & 2.0 & 3.0 & & \\
\hline & & & & & & apex & 1.0 & 3.0 & & \\
\hline & & & & & & periphery & 3.0 & 2.7 & & \\
\hline \multirow[t]{4}{*}{5} & 50.4 & $\mathrm{C}$ & mixed & 2 & 50 & base & 3.7 & 4.0 & 1.9 & + \\
\hline & & & & & & center & 1.3 & 5.0 & 1.2 & + \\
\hline & & & & & & apex & 1.0 & 5.0 & 1.2 & \\
\hline & & & & & & periphery & 2.0 & 4.8 & 1.9 & \\
\hline \multirow[t]{4}{*}{6} & 54.2 & $\mathrm{C}, \mathrm{CB}$ & mixed & 3 & $<10$ & base & 5.0 & 3.0 & 2.0 & \\
\hline & & & & & & center & 2.0 & 3.7 & 1.0 & \\
\hline & & & & & & apex & 2.7 & 3.7 & 2.0 & \\
\hline & & & & & & periphery & 3.0 & 3.0 & 1.5 & \\
\hline 7 & 49.1 & $\mathrm{C}$ & mixed & 3 & 60 & base & 2.0 & 3.0 & & \\
\hline & & & & & & center & 2.0 & 4.0 & & \\
\hline & & & & & & apex & 1.0 & 4.7 & & \\
\hline & & & & & & periphery & 2.7 & 3.7 & & \\
\hline 8 & 70.9 & $\mathrm{C}, \mathrm{CB}$ & mixed & 2 & 100 & base & 5.0 & 4.3 & 2.4 & \\
\hline & & & & & & center & 3.3 & 4.0 & 2.9 & \\
\hline & & & & & & apex & 3.0 & 4.0 & 3.0 & \\
\hline & & & & & & periphery & 3.5 & 4.0 & 2.7 & \\
\hline 9 & 53.8 & $\mathrm{C}, \mathrm{CB}$ & mixed & 3 & 100 & base & 1.7 & 3.7 & 1.9 & \\
\hline & & & & & & center & 2.7 & 3.0 & 1.5 & \\
\hline & & & & & & apex & 2.3 & 2.7 & 1.6 & \\
\hline & & & & & & periphery & 4.3 & 3.3 & 3.2 & + \\
\hline 10 & 59.8 & $\mathrm{C}$ & mixed & 5 & 10 & base & 3.0 & 2.0 & & \\
\hline & & & & & & center & 2.0 & 2.3 & & \\
\hline & & & & & & apex & 3.0 & 2.0 & & + \\
\hline & & & & & & periphery & 2.5 & 2.8 & & \\
\hline 11 & 5.3 & $\mathrm{CB}$ & spindle & 0 & 60 & base & 5.0 & 3.7 & 3.0 & \\
\hline & & & & & & center & 3.7 & 4.3 & 2.0 & + \\
\hline & & & & & & apex & 1.0 & 4.0 & 2.0 & + \\
\hline & & & & & & periphery & 3.0 & 3.8 & 1.0 & + \\
\hline 12 & 18.4 & $\mathrm{C}$ & mixed & 1 & 10 & base & 1.0 & 3.3 & 1.0 & \\
\hline & & & & & & center & 2.0 & 3.7 & 1.0 & \\
\hline & & & & & & apex & 2.7 & 4.3 & 4.0 & \\
\hline & & & & & & periphery & 1.8 & 4.0 & 1.5 & \\
\hline 13 & 23.4 & $\mathrm{C}$ & spindle & 6 & 10 & base & 4.7 & 1.0 & 2.0 & \\
\hline & & & & & & center & 3.3 & 1.7 & 2.0 & \\
\hline & & & & & & apex & 3.7 & 2.0 & 3.0 & \\
\hline & & & & & & periphery & 3.0 & 3.3 & 3.0 & + \\
\hline$\overline{14}$ & 302.6 & $\mathrm{C}$ & mixed & 7 & 100 & base & 5.0 & 4.0 & 4.0 & + \\
\hline & & & & & & center & 3.3 & 4.0 & 1.0 & \\
\hline & & & & & & apex & 5.0 & 3.0 & 2.0 & + \\
\hline & & & & & & periphery & 4.0 & 4.0 & 3.0 & \\
\hline
\end{tabular}

$\mathrm{C}=$ Choroidal $\mathrm{CB}=$ ciliary body.

${ }^{a}$ Histologic types included spindle cells, epithelioid or mixed (spindle plus epithelioid). ${ }^{b}$ Extension of tumor also noted through a vortex vein. 
correlate significantly with metastatic death $[4-6,36,37]$. Thus, for simplicity of analysis, we divided PAS-positive patterns into highly aggressive (i.e., loops and networks) and less aggressive (i.e., straight, parallel, parallel with cross-links, arcs, and arcs with branching) categories. Images were digitally acquired at $40 \times$ and $200 \times$ magnifications (Olympus American, Melville, N.Y., USA).

Tumor morphology was analyzed by H\&E staining. In order to measure tumor area, light-microscopic examination was performed on all histopathologic sections in a masked fashion. Images of all H\&E- and PAS-stained sections were obtained with a digital camera at a magnification of $40 \times$. Tumor boundaries were traced from H\&E-stained sections and areas analyzed using Image Pro Express Software (Media Cybernetics, Silver Spring, Md., USA).

\section{Immunohistochemistry}

In addition to paraffin-embedded tissue, a portion of each tumor in which the architecture was preserved was frozen in OCT by the pathologist immediately after enucleation and serially sectioned $(8 \mu \mathrm{m})$. Slides were fixed with methanol for $10 \min \left(-20^{\circ} \mathrm{C}\right)$ and immunohistochemical analyses were performed.

Total vessels were detected with Alexa Fluor 568-conjugated lectin (Bandeira simplicifolia, a panendothelial binding agent; 1:1,000; Invitrogen, Carlsbad, Calif., USA) [38] and anti-collagen type IV (1:3,000; Sigma Chemical Co., St. Louis, Mo., USA). Mature vessels were detected with $\alpha$-SMA Cy3 conjugate (1:3,000; Sigma Chemical Co.) which specifically binds to pericytes [39]. Neovessels were detected with anti-CD105 (clone SN6, 1:500; Abcam, Cambridge, Mass., USA) which has been shown to have specificity for EC displaying high angiogenic activity in uveal melanoma when compared to other markers (i.e., CD34) $[18,40]$. Proliferating cells were labeled with Ki-67 (1:300; Abcam). Alexa Fluor 568 goat anti-mouse, 488 donkey anti-mouse, and 546 goat anti-rabbit were used as secondary antibodies for anti-collagen type IV, CD105, and Ki-67, respectively (1:500; Invitrogen). Omission of the primary antibody (secondary only) was used as a negative control for nonspecific binding. Cell nuclei were stained for $5 \mathrm{~min}$ with $4^{\prime}, 6^{\prime}$-diamidino-2-phenylindole (DAPI, 1:5,000; Invitrogen).

\section{Scanning of Immunofluorescence and Image Processing}

Serial cross sections of the tumors were examined for the presence of the different markers with a BX51 Olympus upright fluorescence microscope (Olympus American). Tumor cross sections were sequentially scanned by moving the stage in a stepwise fashion to take overlapping pictures of the entire tumor section. Each field was photographed 3 times at either $40 \times$ or $200 \times$ magnification using different filters for the DAPI, Alexa Fluor 488, and 568 signals. Montage images of the tumor, which consisted of 36 or 64 fields $(6 \times 6$ or $8 \times 8$ tiled images, depending on the size of the tissue section), were digitally created with Image-Pro Discovery software.

\section{Tumor Vessel Density Grading}

Three photographs taken at $200 \times$ magnification, with an area of $0.137 \mathrm{~mm}^{2}(0.428 \times 0.320 \mathrm{~mm})$, were analyzed per each tumor area. The basal, central, apical, and peripheral areas of each tumor were chosen to analyze the vessel densities and spatial configuration of neovessels and mature vessels. Montages of the total tumor were created and the tumor was divided into the five specified areas as depicted in figure 1A. Tumor neovessel and mature vessel density was graded in a masked fashion in the designated regions of the tumors by three investigators (Y.P., C.M.C., A.A.). Neovessels and mature vessel densities were graded using a scale ranging from 1 to 5 , depicted with standard photographs. Tumor areas with 0 to $<0.3 \%$ vessels were graded as 1 ; areas with 0.3 to $<1 \%$ vessels were graded as 2 ; areas with 1 to $<2 \%$ vessels were graded as 3 ; areas with 2 to $<5 \%$ vessels were graded as 4 , and areas with $5 \%$ vessels or greater were graded as 5 . The density gradings of the three examiners showed excellent agreement (weighted kappa $=$ 0.83 ) and were averaged for subsequent analyses. Only vessels within the body of the tumors were analyzed. A difference was noted between tumors and normal choroid based on DAPIstained morphology. Using this difference allowed us to exclude normal choroid from the analysis.

\section{Statistical Methods}

The association of neovessels, mature vessels, and cell proliferation densities with tumor area (i.e., base, center, apex, peripheral edges) was examined with Huynh-Feldt-corrected repeated measure analysis of variance and post-hoc paired t-tests. There was no indication that the data failed the sphericity assumption. The number and percent of tumors with highly aggressive PAS staining were calculated for each tumor area. The average neovessel and mature vessel densities were compared within each tumor area with respect to highly aggressive and less aggressive PAS staining using a two-factor analysis of variance, following assessment of test assumptions using Levene's test and residual plots. The relationship between mature tumor blood vessels and known interval level prognostic factors was assessed with Pearson correlation coefficients, while analysis of variance was used for categorical prognostic factors. Results were considered significant if $\mathrm{p} \leq 0.05$.

\section{Results}

Immunofluorescence analysis demonstrated that both neovessels and mature vessels were evident in all tumors, as determined by CD105, $\alpha$-SMA, lectin, and collagen type IV staining (data not shown). The density of mature vessels was significantly elevated $(p=0.042)$ in certain areas of the tumor, while the density of neovessels was equal throughout the tumor $(\mathrm{p}=0.306$; table 2$)$. The density of mature vessels was significantly higher in the basal areas than in the center $(\mathrm{p}=0.018)$, and borderline significantly higher in the apex $(\mathrm{p}=0.083)$.

The density of neovessels versus mature vessels was analyzed in each tumor region. Neovessel density was significantly greater $(3.3 \pm 1.0)$ than mature vessel density $(2.5 \pm 0.9)$ in central areas of the tumor $(\mathrm{p}=0.036)$. The neovessel density was also greater than the mature vessel density in apical $(3.4 \pm 1.0,2.6 \pm 1.4)$ and peripheral areas $(3.4 \pm 1.0,3.1 \pm 0.9)$, but this was not statistically significant $(\mathrm{p}=0.17$ and $\mathrm{p}=0.31$, respectively). The mature vessel density was greater $(3.4 \pm 1.6)$ than neo- 

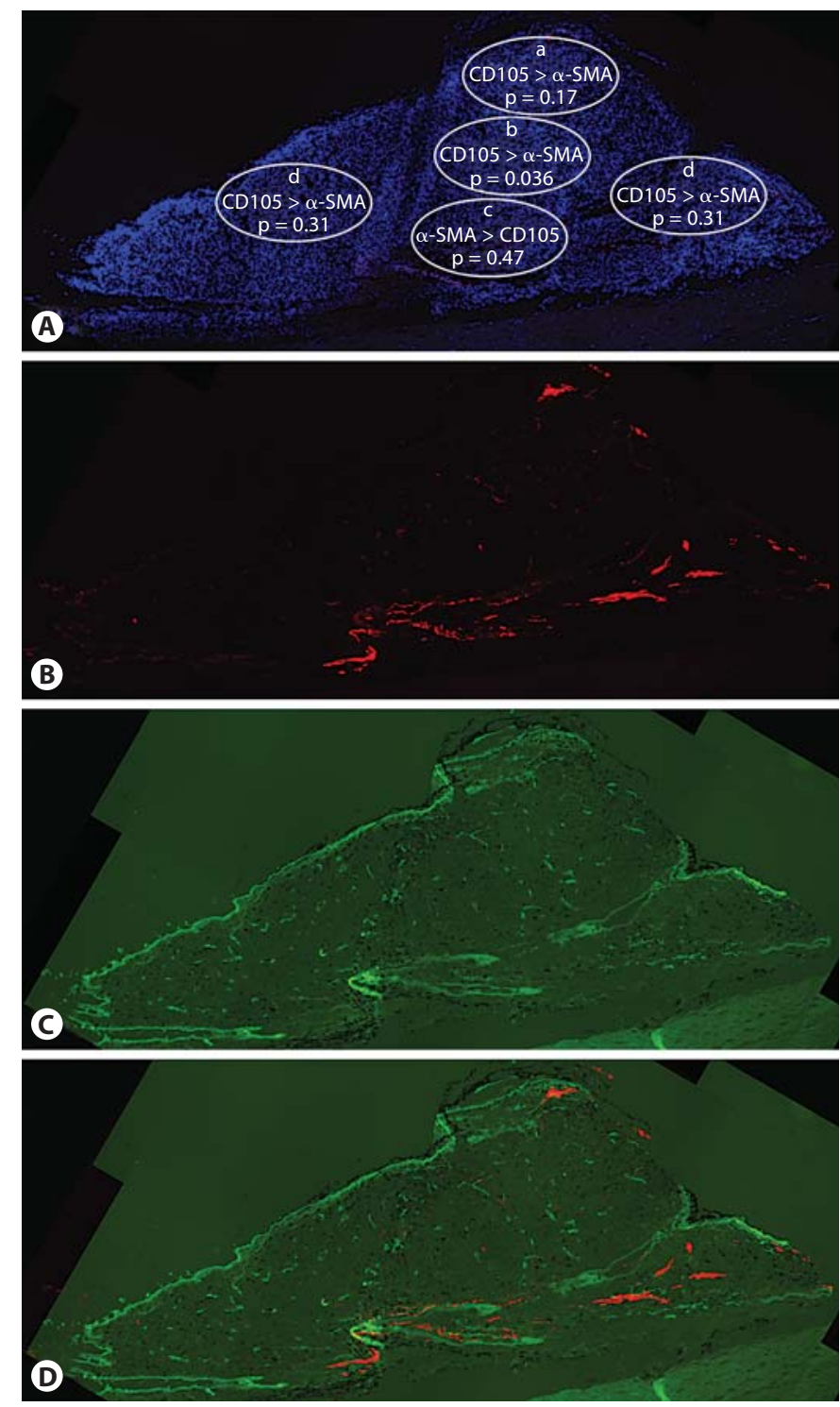

Fig. 1. Distribution of neovessels and mature vessels. A Summary of the distribution of neovessels and mature vessels. The density of neovessels (CD105) is significantly higher than that of mature blood vessels ( $\alpha$-SMA) in central areas of the tumor. Areas are indicated as follows: apex (a), center (b), base (c), periphery (d). DAPI is the blue nuclear stain. B Neovessels (CD105) are distributed throughout the tumor. C Mature tumor blood vessels ( $\alpha$ SMA) are mostly at the tumor base. D Merged image showing both neovessels (CD105, green) and mature blood vessels (labeled with $\alpha$-SMA, red).

vessel density $(3.1 \pm 1.0)$ in basal areas, but this was also not a significant finding $(\mathrm{p}=0.47)$ (table 2; fig. 1$)$.

To determine the pattern of vessel maturation, the difference between neovessels and mature vessel densities was obtained for every tumor area. The differences ob-

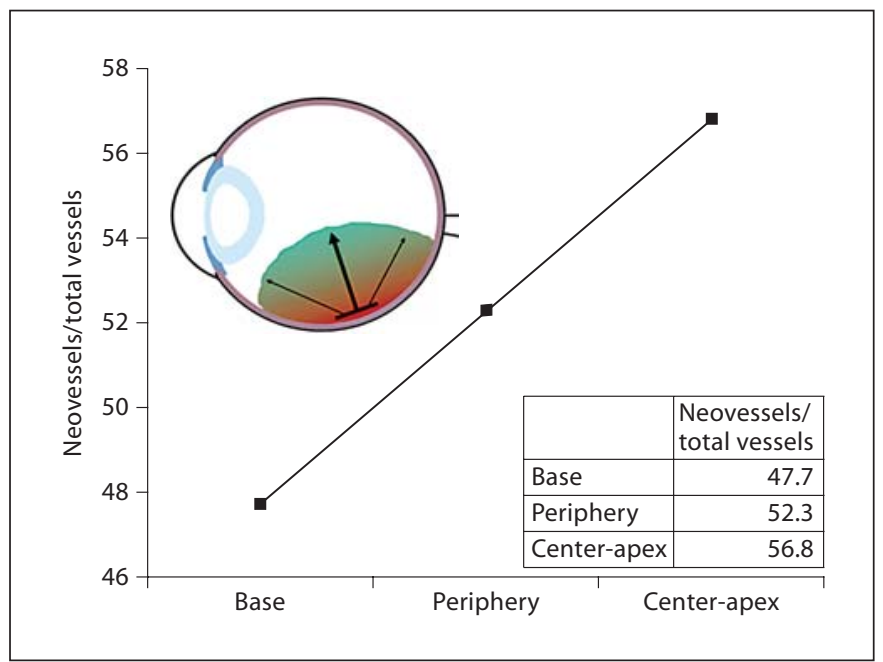

Fig. 2. Model of vessel maturation in uveal melanoma. The developmental pattern of vessel maturation shows a linear and significant increase of the ratio of neovessels to total vasculature, from basal areas of the tumor to leading edges of the tumor. The graph displays the ratio of neovessels to total (neovessels + mature vessels) vessels by tumor area. Inset: Representation of an eye indicating the model of total vasculature pattern of tumor progression.

Table 2. Comparison of the mean $( \pm S D)$ grades of neovessels and mature vessels

\begin{tabular}{llll}
\hline Location & $\begin{array}{l}\text { Mature } \\
\text { vasculature } \\
(\alpha-S M A)\end{array}$ & $\begin{array}{l}\text { Neovessels } \\
(\text { CD105) }\end{array}$ & p value $^{\mathrm{a}}$ \\
\hline Apex & $2.6 \pm 1.4$ & $3.4 \pm 1.0$ & 0.17 \\
Center & $2.5 \pm 0.9$ & $3.3 \pm 1.0$ & 0.036 \\
Periphery & $3.1 \pm 0.9$ & $3.4 \pm 1.0$ & 0.31 \\
$\begin{array}{l}\text { Base } \\
\text { p value }^{\mathrm{b}}\end{array}$ & $3.4 \pm 1.6$ & $3.1 \pm 1.0$ & 0.47 \\
\hline
\end{tabular}

There was a statistically significant interaction between areas and degree of vessel maturation ( $\mathrm{p}=0.044$, two-factor repeated measures analysis of variance test of interaction).

${ }^{a}$ Paired t tests comparing neovessel and mature vessel density within each area.

${ }^{b}$ One-way repeated measures comparison of vessel density within each vessel type.

tained for the apical $(-0.8 \pm 1.9)$ and central areas $(-0.8$ \pm 1.3 ) of the tumor were significantly higher than the difference obtained for the basal area $(\mathrm{p}=0.014$ and $\mathrm{p}=$ 0.012 , respectively). In contrast, the difference obtained for the peripheral areas $(-0.3 \pm 1.1)$ of the tumor was not 

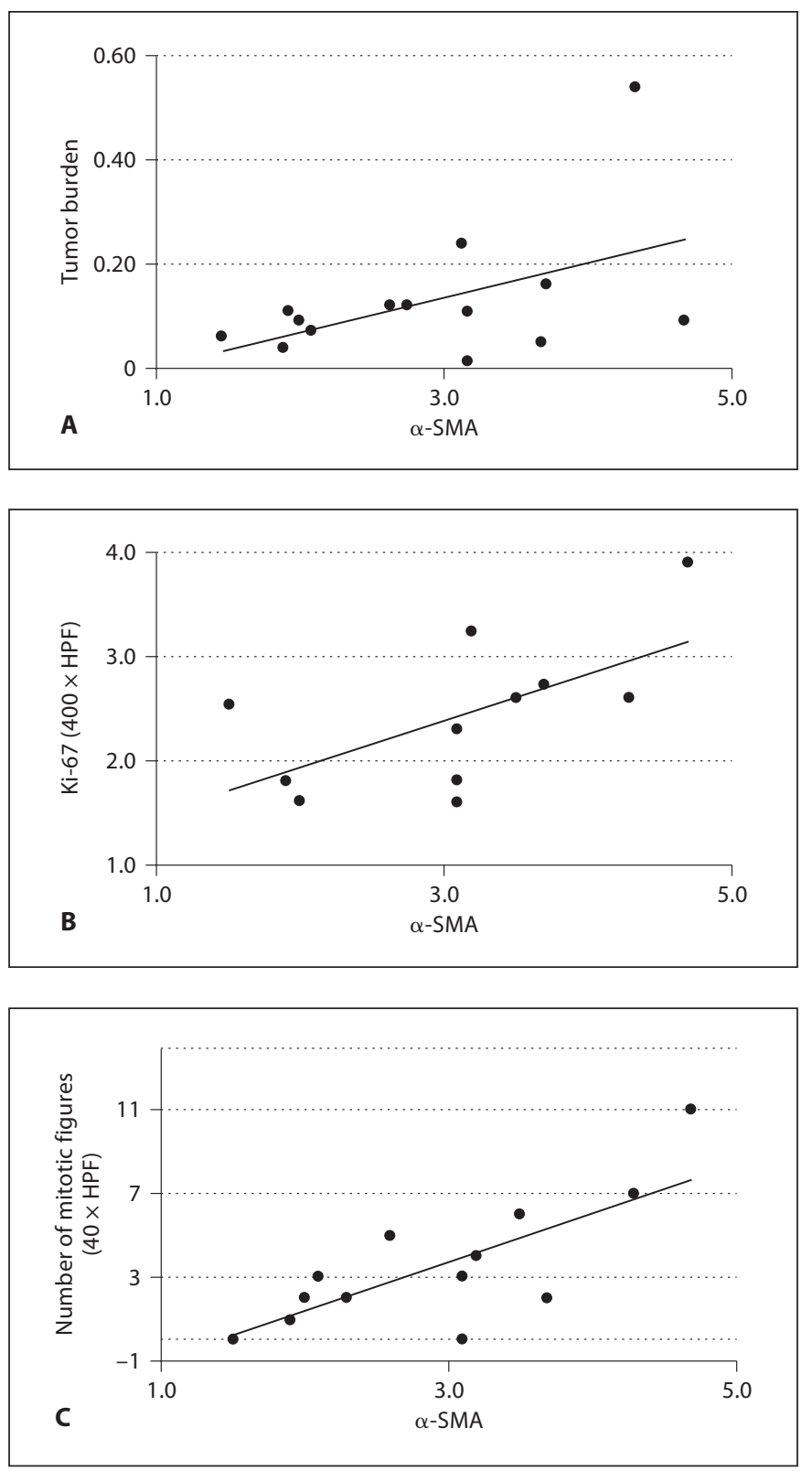

Fig. 3. Correlation between mature vessel density and factors associated with poor prognosis. Graphs showing correlations between mature tumor blood vessels and tumor burden, given as the ratio of the tumor and globe areas $(\mathrm{r}=0.48, \mathrm{p}=0.084)(\mathbf{A})$, cell proliferation density $(\mathrm{Ki}-67, \mathrm{r}=0.62, \mathrm{p}=0.042)(\mathbf{B})$, and number of mitotic figures $(\mathrm{r}=0.76, \mathrm{p}=0.001)(\mathrm{C})$.

significantly different from the difference obtained for the base $(\mathrm{p}=0.14)$. The differences obtained for the apical and central areas of the tumor were similar to each other $(-0.8 \pm 1.9$ and $-0.8 \pm 1.3$, least significant difference post-hoc test, table 3$)$.
Table 3. Comparison of neovessels and mature vessel differences between tumor areas and tumor base

\begin{tabular}{lll}
\hline Location & $\begin{array}{l}\text { Difference } \\
\text { mature vasculature }- \\
\text { neovessels (SD) }\end{array}$ & $\begin{array}{l}\text { LSD post-hoc test } \\
\text { for difference }\end{array}$ \\
\hline Apex & $-0.8(1.9)$ & $\mathrm{p}=0.014^{\mathrm{a}}$ \\
Center & $-0.8(1.3)$ & $\mathrm{p}=0.012^{\mathrm{a}}$ \\
Periphery & $-0.3(1.1)$ & $\mathrm{p}=0.14^{\mathrm{a}}$ \\
Base & $0.3(1.6)$ & \\
\hline
\end{tabular}

Standard deviation is shown in parentheses.

${ }^{\text {a }}$ Each area compared to base with least significant difference (LSD) post-hoc test.

To further examine vessel patterns within the tumor, we used data from table 2 to calculate the ratio of mean neovessels to total vessels (i.e., neovessels + mature vessels) and obtained a percentage value for each area: base $47.7 \%$, periphery $52.3 \%$, center $56.7 \%$, and apex $56.9 \%$. This pattern of vessel maturation is similar to that seen with difference analysis. A model of tumor growth suggested by these percentages is presented in figure 2 .

To test the hypothesis that tumor vessel maturation is correlated with poor prognostic factors, neovessels and mature vessel densities were compared to aggressive PAS patterns, tumor size, epithelioid cell type, extraocular extension, anterior location, mitotic figures, and cell proliferation. No significant associations were found between tumor vasculature and any of the following variables: aggressive PAS patterns, epithelioid cell type, extraocular extension, or anterior location. Associations were found between total tumor vasculature and tumor size, mitotic figures, and cell proliferation. Interestingly, these associations were greater with mature vessel density than with neovessel density (table 4; fig. 3). There was a borderline association between mature vessel density and tumor size $(r=0.48, p=0.084)$, but not with neovessel density $(r=0.11, p=0.72)$. In addition, mature vessel density was associated with cell proliferation density levels $(\mathrm{r}=$ $0.62, p=0.042)$, while neovessel density was not $(r=0.29$, $\mathrm{p}=0.32$ ). Both mature vessels and cell proliferation densities were associated with mitotic figures $(\mathrm{r}=0.76, \mathrm{p}=$ 0.001 and $r=0.72, p=0.013$, respectively), while neovessel density was not $(\mathrm{r}=0.13, \mathrm{p}=0.67)$. Taken together these data suggest that larger tumors have a higher cell proliferation and a higher ratio of mature to neovessel density than smaller tumors. 
Table 4. Pearson's correlation coefficients for mature vessels, neovessels and cell proliferation, factors associated with poor prognosis

\begin{tabular}{llll}
\hline Prognostic factors & $\begin{array}{l}\text { Mature vasculature } \\
(\alpha-S M A, n=14)\end{array}$ & $\begin{array}{l}\text { Neovessels } \\
(\text { CD105, } \mathrm{n}=14)\end{array}$ & $\begin{array}{l}\text { Cell proliferation } \\
(\text { Ki-67, } \mathrm{n}=11)\end{array}$ \\
\hline $\begin{array}{lll}\text { Tumor size } \\
\text { Cell proliferation }\end{array}$ & $\mathrm{r}=0.48(\mathrm{p}=0.084)^{\mathrm{a}}$ & $\mathrm{r}=0.11(\mathrm{p}=0.72)$ & $\mathrm{r}=0.25(\mathrm{p}=0.45)$ \\
Number of mitotic figures & $\mathrm{r}=0.62(\mathrm{p}=0.042)^{\mathrm{b}}$ & $\mathrm{r}=0.29(\mathrm{p}=0.32)$ \\
$\mathrm{r}=0.76(\mathrm{p}=0.001)^{\mathrm{b}}$ & $\mathrm{r}=0.13(\mathrm{p}=0.67)$ & $\mathrm{r}=0.72(\mathrm{p}=0.013)^{\mathrm{b}}$ \\
\hline \multicolumn{2}{l}{${ }^{\text {a Borderline significant correlation. }}$} & & \\
${ }^{\mathrm{b}}$ Statistically significant $\mathrm{p}$ value. & & \\
\hline
\end{tabular}

\section{Discussion}

The survival of growing tumors requires the formation of new blood vessels from preexisting ones [23]. Angiogenesis is a complex and highly dynamic process involving a series of events and a multitude of regulatory factors, many of which can be targets for therapy. Evidence suggests that increased expression of CD105, a homodimeric membrane glycoprotein expressed in ECs and upregulated during angiogenesis in the tumor microenvironment [41, 42], is a major and independent biological marker for poor prognosis in a wide number of human tumors including uveal melanoma [18, 40, 4355]. However, vessel maturation plays an important role in the later stages of tumor development, and experimental studies are lacking on the presence and implication of vessel maturation in human uveal melanoma.

Neovessel formation is inhibited by the use of antiangiogenic agents. ECs in neovessels require growth factors for survival. In their absence, ECs undergo apoptosis and regress [21]. In contrast, mature tumor blood vessels are stabilized by pericytes and are no longer dependent on angiogenic stimuli. The process of vascular maturation results from an intricate association between angiogenic stimulators and inhibitors $[56,57]$. Pericytes are recruited to blood vessels at the time at which angiogenic stimuli halt in the tumor. For instance, blood flow and oxygen supply increase immediately following maturation and overlap with decreased levels of VEGF [56, 57]. Mature tumor blood vessels persist for months in spite of angiogenic factor withdrawal [58]. When pericytes and smooth muscle cells are recruited, vessels stabilize and ECs are less likely to undergo apoptosis, becoming more resistant to antiangiogenic treatments $[21,31,57,59,60]$. This suggests that vessel heterogeneity, in particular the number of mature vessels found in tumors, may limit the efficacy of vessel targeting therapy as previously reported [57, 61]. In addition, vasculogenic mimicry, in which vessels are lined by tumor cells rather than ECs, may limit the effectiveness of vessel targeting therapy. In vitro data indicate that these extravascular channels do not respond to classical antiangiogenic agents [62]. Therefore, when given as monotherapy, antiangiogenic drugs may have limited efficacy in the treatment of uveal melanoma.

Mitotic figures [7, 8], cell proliferation [18], and tumor size $[9,10]$ have all been found to be indicators of poor prognosis and death due to metastasis in melanoma. In this paper, we show that the level of vessel maturation is significantly correlated with the number of mitotic figures and cell proliferation in the tumor. An early trend was found between vessel maturation and tumor size at the time of enucleation. Although high levels of neovessel density have been shown in previous studies to correlate with increased mortality [3-5], in our study mature vasculature was found to correlate better than neovessel density with other poor prognostic indicators (i.e., mitotic figures, tumor size, and cell proliferation).

Our data indicate that significant differences exist in the spatial distribution of neovessels versus mature vessels in human uveal melanoma. When comparing the density of neovessels from one area to another within the tumors, we found that the density of neovessels is equivalent in all areas of the tumor, while the density of mature vessels is mainly concentrated in the base and periphery of the tumor. When comparing the difference of neovessels to mature vessels within each tumor area, we found that the central, apical, and peripheral areas of the tumors expressed a higher density of neovessels than mature vessels. In contrast, in the basal areas of the tumors, a higher density of mature tumor vessels was present than of neovessels. However, at least a low level of vessel maturation was present in all regions. These mature tumor blood 
vessels at the base are most likely to be resistant to antiangiogenic treatments [29, 31, 57], and could increase the chance of extraocular tumor extension $[4,11]$.

Although the choroidal vasculature was excluded in our analysis of mature and neovessels, we believe that the interface between the choroid and the tumor is important in tumor development and tumor vessel maturation. We hypothesize that the pattern of vessel distribution that this study uncovered may be explained by the close proximity of the tumor base to the normal mature vasculature of the choroid, allowing co-optation of already mature choroidal vasculature by the tumor. We believe that the choroidal component of the vasculature initially feeds the tumor at the margins, and as the tumor develops, this bridge to a normal vascular network is gradually lost at the apex. Another potential explanation is that the basal region of the tumor is believed to be the oldest, allowing the most time for increased maturation of the vasculature at the base of the tumor. Thus, these tumors may have dual vascular components: (1) the original component branching from the choroidal vasculature and (2) the neovascular component at the leading edges of the tumor resulting from angiogenesis.

We initially hypothesized that neovessels would localize to the leading edges of the tumor. The data collected in this study support our hypothesis and allow us to propose a model for vessel development in uveal melanoma. Since the ratio of neovessel to total vessel density by tumor location in the apical and central areas was similar (i.e., apex is $56.7 \%$, and center is $56.9 \%$ ), both areas were averaged for representational purposes. The developmental maturational pattern of tumor progression shows a linear and significant increase in the ratio of neovessels to total vasculature, from basal areas of the tumor to leading edges of the tumor (fig. 2). This model provides a potential understanding for spatial tumor vessel maturation associated with progressive tumor development.

Pericytes associated with mature tumor blood vessels have gained new attention as functional and critical contributors to tumor angiogenesis and potential new targets for therapy [29]. Because uveal melanoma detection usually occurs during later stages of tumor development [6365], significant vessel maturation is present. Thus an ideal therapy would include vascular targeting agents which target neovessels as well as agents which target mature vessels such as pericyte-targeting agents [29]. Such a strategy would provide a comprehensive, integrative, therapeutic approach for the treatment of human uveal melanoma.

\section{Acknowledgments}

This study was supported by the NIH center grant R01 EY013629, R01 EY12651, and P30 EY014801, and by an unrestricted grant to the University of Miami from Research to Prevent Blindness, Inc.

\section{References}

1 Damato B: Developments in the management of uveal melanoma. Clin Exp Ophthalmol 2004;32:639-647.

2 Parkin DM, Muir CS: Cancer incidence in five continents. Comparability and quality of data. IARC Sci Publ 1992;120:45-173.

>3 Kilic E, Stijnen T, de Jong PT, Mooy CM, Eijkenboom WM, Ringens PJ, Luyten GP: Reduced melanoma-related mortality in uveal melanoma by preenucleation radiotherapy. Arch Ophthalmol 2005;123:1363-1367.

4 Kujala E, Makitie T, Kivela T: Very long-term prognosis of patients with malignant uveal melanoma. Invest Ophthalmol Vis Sci 2003; 44:4651-4659.

5 Zimmerman LE, McLean IW: Do growth and onset of symptoms of uveal melanomas indicate subclinical metastasis? Ophthalmology 1984;91:685-691.
-6 Folberg R, Pe'er J, Gruman LM, Woolson RF, Jeng G, Montague PR, Moninger TO, Yi H, Moore KC: The morphologic characteristics of tumor blood vessels as a marker of tumor progression in primary human uveal melanoma: a matched case-control study. Hum Pathol 1992;23:1298-1305.

7 McLean IW, Saraiva VS, Burnier MN Jr: Pathological and prognostic features of uveal melanomas. Can J Ophthalmol 2004;39: 343-350.

-8 Lattman J, Kroll S, Char DH, Ghazvini S, Frigillana H, O’Brien JM, Elbakri HR: Cell cycling and prognosis in uveal melanoma. Clin Cancer Res 1995;1:41-47.

$\checkmark$ Diener-West M, Hawkins BS, Markowitz JA, Schachat AP: A review of mortality from choroidal melanoma. II. A meta-analysis of 5 -year mortality rates following enucleation, 1966 through 1988. Arch Ophthalmol 1992; 110:245-250.
10 Seddon JM, Albert DM, Lavin PT, Robinson $\mathrm{N}$ : A prognostic factor study of disease-free interval and survival following enucleation for uveal melanoma. Arch Ophthalmol 1983; 101:1894-1899.

11 Shammas HF, Blodi FC: Orbital extension of choroidal and ciliary body melanomas. Arch Ophthalmol 1977;95:2002-2005.

12 McLean IW, Foster WD, Zimmerman LE: Uveal melanoma: location, size, cell type, and enucleation as risk factors in metastasis. Hum Pathol 1982;13:123-132.

13 Seddon JM, Gragoudas ES, Albert DM, Hsieh CC, Polivogianis L, Friedenberg GR: Comparison of survival rates for patients with uveal melanoma after treatment with proton beam irradiation or enucleation. Am J Ophthalmol 1985;99:282-290.

14 Shammas HF, Blodi FC: Prognostic factors in choroidal and ciliary body melanomas. Arch Ophthalmol 1977;95:63-69. 
-15 McLean IW, Ainbinder DJ, Gamel JW, 29 Bergers G, Song S, Meyer-Morse N, BergMcCurdy JB: Choroidal-ciliary body melanoma. A multivariate survival analysis of tumor location. Ophthalmology 1995;102: 1060-1064.

-16 Makitie T, Summanen P, Tarkkanen A, Kivela T: Tumor-infiltrating macrophages (CD68(+) cells) and prognosis in malignant uveal melanoma. Invest Ophthalmol Vis Sci 2001;42:1414-1421.

17 Makitie T, Summanen P, Tarkkanen A, Kivela $\mathrm{T}$ : Microvascular density in predicting survival of patients with choroidal and ciliary body melanoma. Invest Ophthalmol Vis Sci 1999;40:2471-2480.

-18 Ziemssen F, Wegner R, Wegner J, Tatar O, Susskind D, Gelisken F, Rohrbach M, BartzSchmidt KU, Grisanti S: Analysis of neovasculature in uveal melanoma by targeting the TGFbeta-binding receptor endoglin: is there prognostic relevance of proliferating endothelium? Graefes Arch Clin Exp Ophthalmol 2006;244:1124-1131.

-19 Chen X, Maniotis AJ, Majumdar D, Pe'er J, Folberg R: Uveal melanoma cell staining for CD34 and assessment of tumor vascularity. Invest Ophthalmol Vis Sci 2002;43:25332539.

20 Sisley K, Rennie IG, Parsons MA, Jacques R, Hammond DW, Bell SM, Potter AM, Rees RC: Abnormalities of chromosomes 3 and 8 in posterior uveal melanoma correlate with prognosis. Genes Chromosomes Cancer 1997;19:22-28.

-21 Carmeliet P: Angiogenesis in health and disease. Nat Med 2003;9:653-660.

-22 Rafii S, Lyden D, Benezra R, Hattori K, Heissig B: Vascular and haematopoietic stem cells: novel targets for anti-angiogenesis therapy? Nat Rev Cancer 2002;2:826-835.

23 Folkman J: Seminars in medicine of the Beth Israel Hospital, Boston. Clinical applications of research on angiogenesis. N Engl J Med 1995;333:1757-1763.

24 Rosenblatt MI, Azar DT: Anti-angiogenic therapy: prospects for treatment of ocular tumors. Semin Ophthalmol 2006;21:151-160.

-25 Stitt AW, Gardiner TA: Anti-angiogenic therapy for uveal melanoma - more haste, less speed. Br J Ophthalmol 2002;86:368369.

-26 Yang H, Grossniklaus HE: Combined immunologic and anti-angiogenic therapy reduces hepatic micrometastases in a murine ocular melanoma model. Curr Eye Res 2006; 31:557-562.

-27 Clark AF, Mellon J, Li XY, Ma D, Leher H, Apte R, Alizadeh H, Hegde S, McLenaghan A, Mayhew E, D’Orazio TJ, Niederkorn JY: Inhibition of intraocular tumor growth by topical application of the angiostatic steroid anecortave acetate. Invest Ophthalmol Vis Sci 1999;40:2158-2162.

-28 Bergers G, Benjamin LE: Tumorigenesis and the angiogenic switch. Nat Rev Cancer 2003; 3:401-410. sland E, Hanahan D: Benefits of targeting both pericytes and endothelial cells in the tumor vasculature with kinase inhibitors. J Clin Invest 2003;111:1287-1295.

30 Jockovich ME, Murray TG, Escalona-Benz E, Hernandez E, Feuer W: Anecortave acetate as single and adjuvant therapy in the treatment of retinal tumors of LH(BETA)T(AG) mice. Invest Ophthalmol Vis Sci 2006;47:1264-1268.

31 Jockovich ME, Bajenaru ML, Pina Y, Suarez F, Feuer W, Fini ME, Murray TG: Retinoblastoma tumor vessel maturation impacts efficacy of vessel targeting in the LH(BETA)T(AG) mouse model. Invest Ophthalmol Vis Sci 2007;48:2476-2482.

32 Ozerdem U: Targeting pericytes diminishes neovascularization in orthotopic uveal melanoma in nerve/glial antigen 2 proteoglycan knockout mouse. Ophthalmic Res 2006;38 251-254.

-33 Foss AJ, Alexander RA, Jefferies LW, Hungerford JL, Harris AL, Lightman S: Microvessel count predicts survival in uveal melanoma. Cancer Res 1996;56:2900-2903.

34 Folberg R, Hendrix MJ, Maniotis AJ: Vasculogenic mimicry and tumor angiogenesis. Am J Pathol 2000;156:361-381.

35 Maniotis AJ, Folberg R, Hess A, Seftor EA, Gardner LM, Pe'er J, Trent JM, Meltzer PS Hendrix MJ: Vascular channel formation by human melanoma cells in vivo and in vitro: vasculogenic mimicry. Am J Pathol 1999; 155:739-752.

36 Folberg R, Chen X, Boldt HC, Pe'er J, Brown CK, Woolson RF, Maniotis AJ: Microcirculation patterns other than loops and networks in choroidal and ciliary body melanomas. Ophthalmology 2001;108:996-1001.

37 Niederkorn JY: Enucleation-induced metastasis of intraocular melanomas in mice. Ophthalmology 1984;91:692-700.

38 Laitinen L: Griffonia simplicifolia lectins bind specifically to endothelial cells and some epithelial cells in mouse tissues. Histochem J 1987;19:225-234.

39 Nehls V, Drenckhahn D: Heterogeneity of microvascular pericytes for smooth muscle type alpha-actin. J Cell Biol 1991;113:147154.

40 Tanaka F, Otake Y, Yanagihara K, Kawano Y, Miyahara R, Li M, Yamada T, Hanaoka N, Inui K, Wada $\mathrm{H}$ : Evaluation of angiogenesis in non-small cell lung cancer: comparison between anti-CD34 antibody and antiCD105 antibody. Clin Cancer Res 2001;7: 3410-3415.

41 Fonsatti E, Maio M: Highlights on endoglin (CD105): from basic findings towards clinical applications in human cancer. J Trans Med 2004;2:18.

42 Thorpe PE, Burrows FJ: Antibody-directed targeting of the vasculature of solid tumors. Breast Cancer Res Treat 1995;36:237-251.
43 Dales JP, Garcia S, Carpentier S, Andrac L, Ramuz O, Lavaut MN, Allasia C, Bonnier P, Taranger-Charpin C: Prediction of metastasis risk (11 year follow-up) using VEGF-R1, VEGF-R2, Tie-2/Tek and CD105 expression in breast cancer $(\mathrm{n}=905)$. Br J Cancer 2004; 90:1216-1221.

44 Ding S, Li C, Lin S, Yang Y, Liu D, Han Y, Zhang Y, Li L, Zhou L, Kumar S: Comparative evaluation of microvessel density determined by CD34 or CD105 in benign and malignant gastric lesions. Hum Pathol 2006;37: 861-866.

-45 Erdem O, Taskiran C, Onan MA, Erdem M, Guner H, Ataoglu O: CD105 expression is an independent predictor of survival in patients with endometrial cancer. Gynecol Oncol 2006;103:1007-1011.

46 Li C, Gardy R, Seon BK, Duff SE, Abdalla S, Renehan A, O’Dwyer ST, Haboubi N, Kumar S: Both high intratumoral microvessel density determined using CD105 antibody and elevated plasma levels of CD105 in colorectal cancer patients correlate with poor prognosis. Br J Cancer 2003;88:1424-1431.

47 Marioni G, Ottaviano G, Giacomelli L, Staffieri C, Casarotti-Todeschini S, Bonandini E, Staffieri A, Blandamura S: CD105-assessed micro-vessel density is associated with malignancy recurrence in laryngeal squamous cell carcinoma. Eur J Surg Oncol 2006;32: 1149-1153.

48 Martone T, Rosso P, Albera R, Migliaretti G, Fraire F, Pignataro L, Pruneri G, Bellone G, Cortesina G: Prognostic relevance of CD105+ microvessel density in HNSCC patient outcome. Oral Oncol 2005;41:147-155.

49 Saad RS, Liu YL, Nathan G, Celebrezze J, Medich D, Silverman JF: Endoglin (CD105) and vascular endothelial growth factor as prognostic markers in colorectal cancer. Mod Pathol 2004;17:197-203.

50 Salvesen HB, Gulluoglu MG, Stefansson I, Akslen LA: Significance of CD 105 expression for tumour angiogenesis and prognosis in endometrial carcinomas. APMIS 2003; 111:1011-1018.

51 Straume O, Akslen LA: Expression of vascular endothelial growth factor, its receptors (FLT-1, KDR) and TSP-1 related to microvessel density and patient outcome in vertical growth phase melanomas. Am J Pathol 2001; 159:223-235.

-52 Taskiran C, Erdem O, Onan A, Arisoy O, Acar A, Vural C, Erdem M, Ataoglu O, Guner $\mathrm{H}$ : The prognostic value of endoglin (CD105) expression in ovarian carcinoma. Int J Gynecol Cancer 2006;16:1789-1793.

53 Wikstrom P, Lissbrant IF, Stattin P, Egevad L, Bergh A: Endoglin (CD105) is expressed on immature blood vessels and is a marker for survival in prostate cancer. Prostate 2002; $51: 268-275$ 
54 Yang LY, Lu WQ, Huang GW, Wang W: Correlation between CD105 expression and postoperative recurrence and metastasis of hepatocellular carcinoma. BMC Cancer 2006;6:110.

-55 Yao Y, Kubota T, Takeuchi H, Sato K: Prognostic significance of microvessel density determined by an anti-CD105/endoglin monoclonal antibody in astrocytic tumors: comparison with an anti-CD31 monoclonal antibody. Neuropathology 2005;25:201206.

56 Darland DC, D’Amore PA: Blood vessel maturation: vascular development comes of age. J Clin Invest 1999;103:157-158.

-57 Gee MS, Procopio WN, Makonnen S, Feldman MD, Yeilding NM, Lee WM: Tumor vessel development and maturation impose limits on the effectiveness of anti-vascular therapy. Am J Pathol 2003;162:183-193.
58 Dor Y, Djonov V, Abramovitch R, Itin A, Fishman GI, Carmeliet P, Goelman G, Keshet E: Conditional switching of VEGF provides new insights into adult neovascularization and pro-angiogenic therapy. EMBO J 2002;21:1939-1947.

59 McCarty MF, Liu W, Fan F, Parikh A, Reimuth N, Stoeltzing O, Ellis LM: Promises and pitfalls of anti-angiogenic therapy in clinical trials. Trends Mol Med 2003;9:5358.

60 Reinmuth N, Liu W, Jung YD, Ahmad SA, Shaheen RM, Fan F, Bucana CD, McMahon G, Gallick GE, Ellis LM: Induction of VEGF in perivascular cells defines a potential paracrine mechanism for endothelial cell survival. FASEB J 2001;15:1239-1241.
61 Eberhard A, Kahlert S, Goede V, Hemmerlein B, Plate KH, Augustin HG: Heterogeneity of angiogenesis and blood vessel maturation in human tumors: implications for antiangiogenic tumor therapies. Cancer Res 2000;60:1388-1393.

62 van der Schaft DW, Seftor RE, Seftor EA, Hess AR, Gruman LM, Kirschmann DA, Yokoyama Y, Griffioen AW, Hendrix MJ: Effects of angiogenesis inhibitors on vascular network formation by human endothelial and melanoma cells. J Natl Cancer Inst 2004; 96:1473-1477.

63 Bove R, Char DH: Nondiagnosed uveal melanomas. Ophthalmology 2004;111:554-557.

64 Damato B: Detection of uveal melanoma by optometrists in the United Kingdom. Ophthalmic Physiol Opt 2001;21:268-271.

-65 Eskelin S, Kivela T: Mode of presentation and time to treatment of uveal melanoma in Finland. Br J Ophthalmol 2002;86:333-338. 